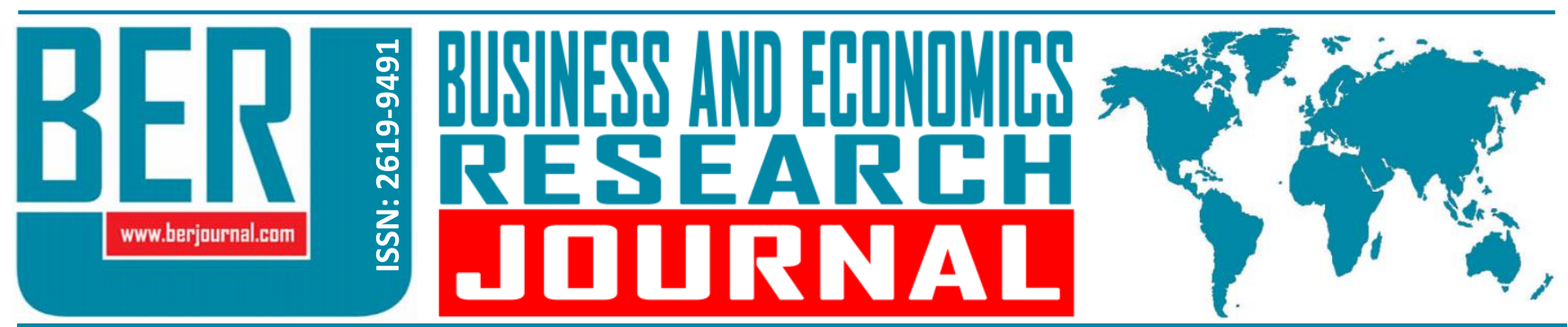

Business and Economics Research Journal Vol. 10, No. 5, 2019, pp. 1095-1108 doi: 10.20409/berj.2019.224

\title{
Passive Consumers, Vulnerabilities and Public Policies
}

\section{Ram Kesavan $^{\mathrm{a}}$, Oswald Mascarenhas ${ }^{\mathrm{b}}$, Michael D. Bernacchic}

Abstract: In this paper we examine a "new" source of consumer vulnerability: the "secondary" consumption of harmful "micro" addictive products and the "primary" consumption of certain "macro" products that are the byproducts of our postindustrial civilization. We define consumer vulnerability of these products in relation to its cognates, disadvantage and detriment, introduce the theory of market imperfections to explain the factual domains of both "micro" and "macro" harmful products to identify the "new" vulnerable consumers, investigate the social concerns surrounding these products, and explore some feasible solutions for protecting them from their vulnerabilities.

\author{
Keywords: Consumer \\ Vulnerability, Business Ethics, \\ Market Imperfections, Micro \\ and Macro Harmful Products, \\ Joint-Responsibility \\ JEL: F60, I10, I30, M30 \\ Received : 18 May 2019 \\ Revised : 10 July 2019 \\ Accepted : 20 August 2019 \\ Type \\ : Conceptual Paper
}

\section{Introduction}

The focus of this paper is on consumer vulnerability in relation to its cognates, disadvantage and detriment, introduce the theory of market imperfections to explain the factual domains of both "micro" and "macro" harmful products to identify the "new" vulnerable consumers. We also investigate the social concerns surrounding these products, and explore solutions for protecting the "new" consumers from their vulnerability.

There has been much interest among researchers regarding vulnerable consumers (Gellad et al, 2006; Timmermann, 2009; Wilson \& Sheehan, 2009; Bartl, 2010; Garrett \& Toumanoff, 2010; Harrison \& Gray, 2010; Chan \& Ghani, 2011; Wilson, 2012; Berg, 2015; Balázs et al., 2017; Knobel, 2018; Graham, 2018). The domain of "vulnerables" are primarily the poor and powerless who pay more (Caplovitz, 1963; Goodman, 1968; Hudson, 1993), the ethnically disadvantaged consumers (Andreasen 1975, 1982, 1993) and the ghetto communities (Sturdivant, 1969; Andreasen, 1997). Young consumers and senior citizens are vulnerable because they have problems in their purchase, use and disposition of products (Patterson et al., 1992; Andreassen, 1993). Their vulnerabilities relate to defective products that cause harm (Stern \& Eovaldi, 1984), racial stereotyping and target marketing of ethnic minorities based on their alleged higher propensity to consume tobacco and alcohol products (Spratlen, 1992). There's a growing interest in new vulnerable consumer segments including the poor or the powerless, the ethnic (or religious) minorities, or the ghetto communities among others (Haviland et al., 2011; Wilson, 2012). Figures 1 details consumer vulnerability.

\footnotetext{
Cite this article as: Kesavan, R., Mascarenhas, O., \& Bernacchi, M. D. (2019). Passive consumers, vulnerabilities and public policies. Business and Economics Research Journal, 10(5), 1095-1108.

The current issue and archive of this Journal is available at: www.berjournal.com

Prof., PhD., University of Detroit Mercy, Detroit, MI, USA, RamKesavan60@gmail.com (ORCID ID: 0000-0002-0171-2865)

b Prof., PhD., S.J., Xavier Labor Relations Institute, Jamshedpur, India (ORCID ID: 0000-0001-9213-6738)

Prof., PhD., University of Detroit Mercy, Detroit, MI, USA, (ORCID ID: 0000-0001-6801-655X)
} 
Figure 1. Dimensions of Consumer Vulnerability

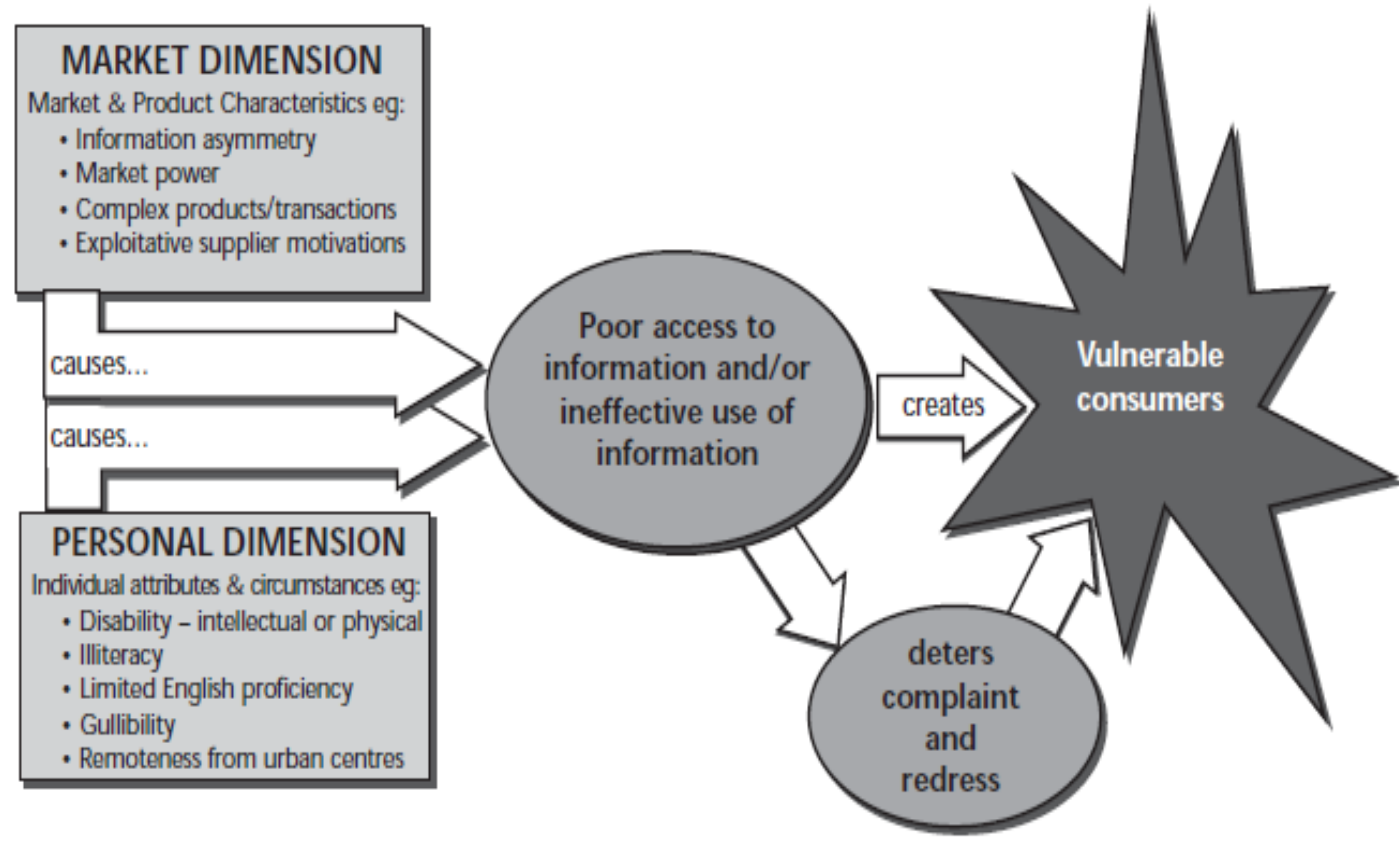

Source: www.consumer.vic.gov.au

Included among vulnerable segments are "secondary" consumers of addictive "micro" products (such as alcohol, cigarettes, fatty foods, gambling and illegal drugs) and consumers of other corporate and social "macro" products (such as industrial smog and waste, industrial downsizing and outsourcing). Recently, corporate white-collar crimes and frauds and their economic negative effects on customers, suppliers, employees, shareholders, governments and global communities are also included. The social externalities of these "micro" and "macro" products are significant.

\section{Consumer Vulnerability, Disadvantage and Detriment}

Vulnerability implies forced choice or consumption or an inability to reject an object or behavior. The term vulnerability (vulnerare $=$ to wound, to harm or to assail in Latin) etymologically implies the capability of being physically wounded or open to attack, harm or damage. A person's vulnerability is one's likelihood of being easily injured or harmed. This implies a state of exposure to the chance (or risk) of injury or loss (Springhart \& Thomas, 2017). This concept of vulnerability is of extreme importance in our fast-paced, hightech and dynamic world where today's invulnerability becomes tomorrow's vulnerability.

\subsection{Vulnerability and Disadvantage}

An unfavorable and unchangeable condition makes one "naturally" disadvantaged (Rawls 1971). An unfavorable circumstance can make one "socially" disadvantaged (Andreasen 1975, 1982, 1993). Disadvantage from socially structured obstacles (e.g., market imperfections) inadequately impact one's access to resources, benefits and opportunities. For instance, certain personal traits cannot be changed (e.g., gender, age, race, ethnicity and color). Also, some unfavorable circumstances (e.g., poverty, ill-health, illiteracy, inability to speak English) are not easily changed.

\subsection{Vulnerability and Consumer Detriment}

Consumer vulnerability and disadvantage lead to consumer detriment. Consumer detriment occurs at several levels:

- Physical injury, illness or death brought by the use of a product or service (Stern \& Eovaldi, 1984). 
- Economic denial of access to basic resources as education, welfare and healthcare, loss of income, loss of job, deprivation of basic utilities (Hudson, 1993).

- Social loss of social status brought by the loss of one's job or income, loss of one's pattern or style of consumption due to loss in income, loss due to discrimination, red lining, gender bias (Purviance, 1993), or social stereotyping (Cowan, 1979).

- Political or undue discrimination for belonging to one political party or the deprivation of one's due process, or racial and color discrimination (Williams, 1991).

- Ontological is unjust deprivation of human rights to live, be free, be human, or to raise a family or to pursue happiness (Rawls, 1971).

Consumer detriment is not mutually exclusive or exhaustive. Human or consumer vulnerability is too involved and complex for clear and accurate categories. Vulnerability is 1 or more of the aforementioned 7 dimensions of harm. All harm aspects imply a detriment to one's rights, interests, consumption or values. Some harm forms are temporary (e.g., unemployment, underemployment). They depend on their caused circumstances (e.g., plant closings, offshore outsourcing, economic depression). Some are permanent (e.g., genetic conditioning, chronic illness, mental impairment, physical handicap).

Consumer vulnerability, disadvantage and/or detriment relate to 3 levels of consumer existence: doing (e.g., shopping, purchasing, using, consuming, raising family), becoming (e.g., growing, maturing, fulfilling, trusting, caring) and being (e.g., self-actualizing, transcending, hoping, believing, being immortal). Conventional consumer vulnerability focuses on doing relates to physical harm. Consumer vulnerability in becoming relates to economic, social, political and psychological levels of harm. Consumer vulnerability in being relates to spiritual and ontological harm.

\section{Market Imperfections Create Harmful Micro/Macro Products}

We next explore the new sources of vulnerability, disadvantage and detriment in our postindustrial civilization. First, we note there are two sets of harmful products:

- "Micro" market offerings are commercially made by firms to consumers. They bring about vulnerability, disadvantage and detriment to consumers and/or bystanders (i.e., addictive products such as alcohol, cigarettes, drugs and gambling, and fatty foods).

- "Macro" products are market impositions by firms, governments and societies on all consumers that cause harm. They include: industrial smog and waste, industrial downsizing, massive layoffs and offshore outsourcing of jobs, corporate frauds and bankruptcies, national terrorism and homeland security constraints, and national socio-moral unrest.

"Micro" products do not necessarily have a "defect" defined by strict liability. They nonetheless, can cause harm to consumers and bystanders. They cause harm to "primary"/direct consumers when overindulged and to "secondary" consumers who do not directly consume them but, nevertheless, experience harm because of their close association (e.g., children, siblings, relatives, workmates) with those that do. Sheth and Mittal (2003) define "passive" consumers who are not consuming the products themselves, but as bystanders, are negatively impacted by other's consumption. "Secondary" approximate "passive" consumers. Most commonly "secondary" consumers are children of chain smokers at home, alcoholic or obese parents, pathological gamblers, and drug-addicts. These are "new" vulnerables who are secondary consumers of harmful micro products.

The second set of "macro" products are not real "products" in the sense that marketplace, but they are by-products of the organizations and institutions that produce and consume most products and services. They are "defective" because they cause harm to those who unavoidably are exposed to them. Strict liability's normal recovery modalities do not apply to them, yet they result in harm. We call their result "product" a "new" form of vulnerability with no formal legal precedent to protect consumers from it. 


\subsection{Consumer Vulnerability and Market Imperfections}

A forced choice and/or use of a good or service imply various levels of constraints and, vulnerability, brought about by structural forces called market imperfections. They include:

1. Lack of proper alternative products/services. Their markets are underserved (Caplovitz, 1963; Hudson, 1993).

2. Lack of adequate product/service substitutes, particularly for the poor (Sturdivant, 1969) and inner-city healthcare (Outka, 1987; Loewy, 1993; Seiders \& Petty, 2004).

3. Lack of ability (e.g., physical, economic, psychological, social or political) or resources (e.g., capital, time and skills) to create alternative products or services under (1). Typically, a redlining of donor organs (Purviance, 1993) and housing (Williams, 1995).

4. Similar lack of ability to create adequate substitute products/services under (2).

5. Asymmetric information that follows and causes market imperfections (1) to (4) (Morris et al., 1992; Williams, 1995).

6. Under (1) to (4), the lack of recourse/capacity to complain (Andreasen \& Manning, 1990) primarily because of (5).

7. Lack of redress given a complaint (Caplovitz, 1963; Karpatkin, 1999).

8. Reinforcing market imperfections (1) to (7), the undue target marketing and racial stereotyping in advertising (Smith \& Cooper-Martin, 1997; Spratlen, 1992).

9. Exorbitant pricing under shortages (1) and (2), especially of life-saving drugs (Calfee \& Bate, 2004; Kennedy et al, 2004).

10. Complex infrastructure or structure of products/services under (1) or (2) (Borgmann, 2000; Watson et al., 2004).

11. Under (1) or (2), market power that controls available products/services (Deighton \& Grayson, 1995; Karpatkin, 1999; Davidson, 2003).

12. Because of (3) to (11), high gullibility or vulnerability (i.e., lack of expert, coercive, legitimate or referent power) of consumers (Nason, 1989).

Market imperfections (1) to (12) generate consumer vulnerability in relation to both doing and becoming. The more levels (1) to (12) of forced choices impact our purchases and consumption, the higher is the level of market imperfections. Higher is consequential vulnerability and disadvantage.

\subsection{The "New" Vulnerable Consumers}

We'll investigate the factual domains of "micro" and "macro" harmful products based on their producers, disadvantaged "secondary" passive consumers, and consequent consumer detriment (Berg, 2015; Balázs et al., 2017; Graham, 2018; Knobel, 2018).

\subsection{The Domain of "Micro" Harmful Products}

We list these "micro" harmful products in Table 1, described by their implied market imperfections that generate consumer vulnerability, disadvantage and detriment.

\subsubsection{Secondary Smoking}

Those who smoke or are addicted to tobacco are "primary" consumers. Breathing other people's smoke is "secondary" consumption. It is passive, involuntary or second hand smoking (Arguder, 2017; Dey, 2017). Environmental tobacco smoke (ETS) is indoor pollution. Approximately 53,000 nonsmoking U.S. adults are killed annually due to second hand smoking (Glantz \& Parmley, 1995; He et al., 1999; Mclntyre, 2004). 
Yearly, smoking around U.S. children hospitalizes 15,000 of them. 26,000 new cases of asthma, 150,000 to 300,000 lung infections, and 40\% of SIDS (Sudden Infant Death Syndrome) are due to some in these kids' homes smoking (Benton County Health Department Report). These market imperfections can be overcome. Heart attacks significantly dropped when smoking was banned in public places (Carey \& Gross, 2004).

"Secondary" consumption also occurs because of smoking through peer pressure, movies and ads. And, yes, youth is influenced by peer pressure to smoke (Crisp, 1987) and by tobacco ads and promotions (Deighton \& Grayson, 1995). The extensive depiction of smoking in feature films has also caught children's attention. Involuntary persuasion is a growing market imperfection that must be altered.

\subsubsection{Casino and Internet Gambling}

Casino landline and online gambling currently generate more than $65 \%$ of the U.S. market of gambling revenues. According to the National Gambling Impact Study Commission's 1999 Final Report (NGISC), the pathology of casino gambling addiction is far beyond the 15 million Americans who are pathological gamblers. Estimates of gambling addiction in America exceed 20 million victims (Reno, 1996). These are the "primary" consumers of gambling. The states with an inordinate need for "sin tax revenues" are under great pressure to expand their consumer and revenue bases by easing age restrictions on casino gambling. This strategy targets younger generations who possess few coping defenses against gambling (Volberg, 1995; Shaffer \& Hall, 1996). Gambling casinos, and Internet gambling add "new and improved" devices to extract more and more monies from lower income-populations (Abbott \& Cramer, 1993; Reno, 1996; Watson et al., 2004). Casino gamblers cause problems at work or with relationships (Pasternak, 1997). As gambling related promotions increase, so does crime (e.g., credit card theft, suicide), personal bankruptcy filings, and unemployment rate in the neighboring communities. Those facing economic and domestic crisis (e.g., divorce or single parenting) because of pathological gambling grows (Nichols et al., 2000). All cities, businesses and people impacted by casino gambling are "secondary" consumers.

Table 1. Characterizing the Domain of Harmful Micro Products

\begin{tabular}{|l|l|l|l|}
\hline $\begin{array}{l}\text { Harmful } \\
\text { Micro Products }\end{array}$ & $\begin{array}{l}\text { Market Imperfections } \\
\text { that Generate Harmful } \\
\text { Micro Products }\end{array}$ & $\begin{array}{l}\text { The Disadvantaged } \\
\text { Consumers of Harmful } \\
\text { Micro Products }\end{array}$ & $\begin{array}{l}\text { Consumer Detriment of Harmful } \\
\text { Micro Products }\end{array}$ \\
\hline $\begin{array}{l}\text { Other Tobacco } \\
\text { Products }\end{array}$ & $\begin{array}{l}\text { Tobacco companies, tobacco } \\
\text { media, heavy smokers. }\end{array}$ & $\begin{array}{l}\text { Affected nonsmokers, } \\
\text { bystanders, peer-pressured } \\
\text { teens, media-pressured } \\
\text { tobacco addicts. }\end{array}$ & $\begin{array}{l}\text { Inhaling tobacco smoke causes } \\
\text { serious health problems and } \\
\text { occasionally, deaths. High incidence } \\
\text { and costs of asthma, bronchitis and } \\
\text { lung cancer related illnesses and } \\
\text { deaths among secondary smokers. }\end{array}$ \\
\hline $\begin{array}{l}\text { Spirits, Beer and } \\
\text { Wine }\end{array}$ & $\begin{array}{l}\text { Producers, promoters and } \\
\text { distributors of alcohol } \\
\text { products. The alcoholics and } \\
\text { other drunken orgies }\end{array}$ & $\begin{array}{l}\text { Family members, co- } \\
\text { workers, public at-large } \\
\text { unduly exposed to alcohol } \\
\text { products and alcoholic } \\
\text { behaviors. }\end{array}$ & $\begin{array}{l}\text { Deaths due to excessive alcohol } \\
\text { consumption, injuries and deaths } \\
\text { caused by drunken drivers, lost } \\
\text { productivity, higher insurance } \\
\text { premiums, family tensions and } \\
\text { suffering. }\end{array}$ \\
\hline Illegal Drugs & $\begin{array}{l}\text { Producers, promoters and } \\
\text { distributors of illegal drugs; } \\
\text { crack houses; drug addicts; } \\
\text { drug consumers; drug dens. }\end{array}$ & $\begin{array}{l}\text { Families of drug addicts; } \\
\text { social victims of drug-driven } \\
\text { crimes and crack houses; } \\
\text { children of drug-addicted } \\
\text { parents. }\end{array}$ & $\begin{array}{l}\text { Diseases, deaths, crimes and injuries } \\
\text { caused by drug addicts. Biologically } \\
\text { defective and mentally impaired } \\
\text { children of drug consumers. Family } \\
\text { ruin brought about drug addictions. }\end{array}$ \\
\hline Casino Gambling & $\begin{array}{l}\text { Casinos, casino media, } \\
\text { Internet gambling, casino or } \\
\text { Internet gambling addicts }\end{array}$ & $\begin{array}{l}\text { Family members, friends, } \\
\text { coworkers; local small } \\
\text { businesses affected by } \\
\text { casinos and gambling } \\
\text { addicts. }\end{array}$ & $\begin{array}{l}\text { Suffering, family breakdowns, } \\
\text { bankruptcies; lost work and revenues } \\
\text { and lower productivity brought } \\
\text { about by pathological casino } \\
\text { gamblers. }\end{array}$ \\
\hline
\end{tabular}


Table 1. Characterizing the Domain of Harmful Micro Products (Continued)

\begin{tabular}{|c|c|c|c|}
\hline $\begin{array}{l}\text { Harmful } \\
\text { Micro Products }\end{array}$ & $\begin{array}{l}\text { Market Imperfections } \\
\text { that Generate Harmful } \\
\text { Micro Products }\end{array}$ & $\begin{array}{l}\text { The Disadvantaged } \\
\text { Consumers of Harmful } \\
\text { Micro Products }\end{array}$ & $\begin{array}{l}\text { Consumer Detriment of Harmful } \\
\text { Micro Products }\end{array}$ \\
\hline Fatty Foods & $\begin{array}{l}\text { Fast food chains, fatty meat } \\
\text { producers, fatty menus and } \\
\text { dessert producers in } \\
\text { restaurants, and fatty } \\
\text { dinners at home. }\end{array}$ & $\begin{array}{l}\text { Families that do not cook at } \\
\text { home but totally depend } \\
\text { upon fatty foods from retail } \\
\text { outlets; obese parents that } \\
\text { force fatty meals on } \\
\text { children. }\end{array}$ & $\begin{array}{l}\text { Obesity and deaths due to obesity, } \\
\text { cholesterol and over-weight related } \\
\text { health problems, increased health } \\
\text { insurance premiums, lack of self- } \\
\text { esteem when obese, and fatty food } \\
\text { addictions. }\end{array}$ \\
\hline Pornography & $\begin{array}{l}\text { Producers, promoters and } \\
\text { peddlers of offline and } \\
\text { online pornographic } \\
\text { products. Sexaholics and } \\
\text { pedophiliacs. }\end{array}$ & $\begin{array}{l}\text { Spouses and children of } \\
\text { porno addicts, victims of } \\
\text { pornography peddling in } \\
\text { schools, and victims of child } \\
\text { sexual abuse. }\end{array}$ & $\begin{array}{l}\text { Sex addictions, incest, victimized and } \\
\text { traumatized children, pedophiles, } \\
\text { dysfunctional marriages, loss of self- } \\
\text { esteem, teenager sex and } \\
\text { promiscuity. }\end{array}$ \\
\hline Guns and Firearms & $\begin{array}{l}\text { Producers, promoters, } \\
\text { distributors, owners and } \\
\text { users of guns and firearms }\end{array}$ & $\begin{array}{l}\text { Family members, co- } \\
\text { workers, shopkeepers, } \\
\text { pedestrians and police } \\
\text { officers victimized by gun } \\
\text { abuse and proliferations. }\end{array}$ & $\begin{array}{l}\text { Deaths, serious injuries, permanent } \\
\text { disabilities, psychological trauma, } \\
\text { and increased societal costs of gun } \\
\text { control enforcement and liabilities. }\end{array}$ \\
\hline $\begin{array}{l}\text { Children's War } \\
\text { Toys }\end{array}$ & $\begin{array}{l}\text { Producers, promoters and } \\
\text { distributors of war toys. } \\
\text { Forced toy obsolescence. }\end{array}$ & $\begin{array}{l}\text { Children unduly exposed to } \\
\text { and victimized by war toys; } \\
\text { parents and siblings of these } \\
\text { children. }\end{array}$ & $\begin{array}{l}\text { Toy addictions. Child-victims of } \\
\text { violence-inducing toys. Non- } \\
\text { degradable toy litter on land and } \\
\text { water; dangerous toys. }\end{array}$ \\
\hline $\begin{array}{l}\text { Industrial Food } \\
\text { Pollution }\end{array}$ & $\begin{array}{l}\text { Producers and diffusers of } \\
\text { toxic chemicals into land, } \\
\text { water, air, preserved and } \\
\text { processed foods. }\end{array}$ & $\begin{array}{l}\text { Consumers of industrially } \\
\text { polluted foods, minerals, } \\
\text { waters, preserved and } \\
\text { processed foods. }\end{array}$ & $\begin{array}{l}\text { Temporary or chronic disorders of } \\
\text { stomach, lungs, kidney, heart, blood } \\
\text { and other vital organs and processes } \\
\text { brought about by polluted foods. }\end{array}$ \\
\hline
\end{tabular}

\subsubsection{Fatty Foods and Obesity}

Consumption of fatty foods continues to increase and various forms of obesity are becoming genetically conditioned (Dietz, 1991). The food industry and food marketing practices in obesity is significant (Seiders \& Petty, 2004). They are "secondary" consumers of fatty foods and obesity. Both overweight and obesity has escalated worldwide (Wansink, 2016), and is turning into a public health epidemic (Flegal et al., 2002; Seiders \& Petty, 2004). Obesity costs $\$ 117$ billion a year in the U.S. and records the second highest number of deaths in the U.S. when compared to other addictive products. Obesity kills about 300,000 Americans each year (Manson \& Bassuk, 2003). Obesity equals smoking as the leading preventable cause of disease and death (Seiders \& Petty, 2004).

\subsubsection{Popularity of Processed Foods}

Passive process foods consumption has greatly grown due to increased time pressures making consumers more vulnerable to the decreasing quality of community health. The majority of foods we humans consume are processed (usda.com). In a study that span across nineteen European countries, Monteiro et al (2018) found a significant positive association between consumption of processed foods and national prevalence of obesity.

Specifically, fast food restaurants have increased the spread of cheap and unhealthy processed foods. McDonalds has global reach. A positive association was found between availability of processed foods and national prevalence of obesity (usda.com). 
Figure 2. The Modern Food Sector's Growth in China

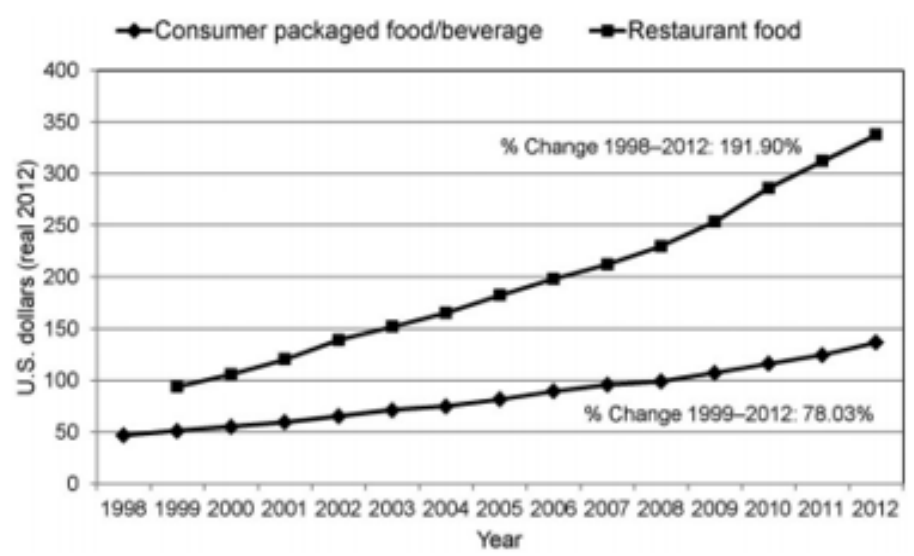

Source: Obesity Research, 2014.

Time scarcity relates to a higher intake of fast foods (Jannsen et al., 2018). Time use studies show that time spent on food preparation decreased nearly $40 \%$ in the last 30 years. Restaurant Consumptionindirect surrogate consumption of processed food- is more common (see Figure 2). The consumption of processed foods is associated with an increased risk of diet related non-communicable diseases with greater risks for cancer.

\subsection{The Domain of "Macro" Harmful Products}

Harmful "macro" products are those products/services that are directly (or indirectly) produced. They're diffused by our complex civilization of industries, corporations, governments, consumers and social mores. They generate consumer, social and national harm. They include industrial waste, industrial downsizing, industrial offshore outsourcing. They also include corporate bankruptcies, our fear of national and global terrorism, industrial and social noise, and national and sociomoral unrest. Table 2 briefly touches on a few of these macro products.

Table 2. Characterizing the Domain of Harmful Macro Products

\begin{tabular}{|l|l|l|l|}
\hline $\begin{array}{l}\text { Harmful } \\
\text { Pacro- }\end{array}$ & $\begin{array}{l}\text { Market Imperfections that } \\
\text { Generate Harmful Macro } \\
\text { Products }\end{array}$ & $\begin{array}{l}\text { The Disadvantaged } \\
\text { Consumers of Harmful } \\
\text { Macro Products }\end{array}$ & $\begin{array}{l}\text { Consumer Detriment of Harmful } \\
\text { Macro Products }\end{array}$ \\
\hline $\begin{array}{l}\text { Industrial } \\
\text { Waste }\end{array}$ & $\begin{array}{l}\text { Oil refineries, steel plants, } \\
\text { fertilizer, chemicals and drugs } \\
\text { factories, nuclear power plants, } \\
\text { and other pollutant industries. }\end{array}$ & $\begin{array}{l}\text { Communities close to polluted } \\
\text { areas, landfills of toxic waste, } \\
\text { abandoned railroads, } \\
\text { shipyards, and mined areas. }\end{array}$ & $\begin{array}{l}\text { Land, water and air pollution } \\
\text { generated by industrial waste; ill } \\
\text { health, depleted neighborhoods and } \\
\text { other social problems. }\end{array}$ \\
\hline $\begin{array}{l}\text { Industrial } \\
\text { Downsizing }\end{array}$ & $\begin{array}{l}\text { Industrial plant closings, plant } \\
\text { relocations, plant redesigns, } \\
\text { automations and robotics }\end{array}$ & $\begin{array}{l}\text { Victims of massive layoffs, } \\
\text { underemployment, skills- } \\
\text { obsolescence and lack of } \\
\text { retraining opportunities. }\end{array}$ & $\begin{array}{l}\text { Ghost towns, forced migration of } \\
\text { workers and families to plant } \\
\text { relocations, job losses due to } \\
\text { automation and induced poverty. }\end{array}$ \\
\hline Outsourcing & $\begin{array}{l}\text { Domestic and offshore } \\
\text { outsourcing of jobs for cost- } \\
\text { containment. }\end{array}$ & $\begin{array}{l}\text { Citizens trained in back-office } \\
\text { jobs, business processing or } \\
\text { programming are jobless, fired, } \\
\text { early retired, or } \\
\text { underemployed. }\end{array}$ & $\begin{array}{l}\text { Job stress and uncertainty among } \\
\text { survivors; loss of jobs, income, } \\
\text { healthcare benefits and prosperity } \\
\text { among the victims of industrial } \\
\text { outsourcing. }\end{array}$ \\
\hline $\begin{array}{l}\text { Industrial } \\
\text { Frauds }\end{array}$ & $\begin{array}{l}\text { Corporate agents that indulged } \\
\text { in fraudulent accounting, insider } \\
\text { trading, and other illegal or } \\
\text { deceptive practices. }\end{array}$ & $\begin{array}{l}\text { All stakeholders of the } \\
\text { fraudulent corporations: e.g., } \\
\text { consumers, suppliers, } \\
\text { creditors, employees, } \\
\text { shareholders and governments } \\
\text { and local communities. }\end{array}$ & $\begin{array}{l}\text { Loss in jobs, wages, bonuses, 401K } \\
\text { funds of employees; loss in quality } \\
\text { products and services to consumers; } \\
\text { loss in revenues, market share and } \\
\text { profits to company, suppliers and } \\
\text { loss of dividends to shareholders. }\end{array}$ \\
\hline
\end{tabular}


Table 2. Characterizing the Domain of Harmful Macro Products (Continued)

\begin{tabular}{|l|l|l|l|}
\hline $\begin{array}{l}\text { Harmful } \\
\text { Macro- } \\
\text { Products }\end{array}$ & $\begin{array}{l}\text { Market Imperfections that } \\
\text { Generate Harmful Macro } \\
\text { Products }\end{array}$ & $\begin{array}{l}\text { The Disadvantaged } \\
\text { Consumers of Harmful } \\
\text { Macro Products }\end{array}$ & $\begin{array}{l}\text { Consumer Detriment of Harmful } \\
\text { Macro Products }\end{array}$ \\
\hline $\begin{array}{l}\text { Industrial } \\
\text { Bankruptcies }\end{array}$ & $\begin{array}{l}\text { Large and small corporations, } \\
\text { small businesses, governments, } \\
\text { organizations and individuals. }\end{array}$ & $\begin{array}{l}\text { All stakeholders, especially } \\
\text { creditors, suppliers, } \\
\text { shareholders, employees, } \\
\text { consumers and local } \\
\text { communities. }\end{array}$ & $\begin{array}{l}\text { Social stigma and loss of assets for } \\
\text { the bankrupt entities; much anxiety } \\
\text { and loss of money, jobs, healthcare } \\
\text { benefits, pensions, products or } \\
\text { services for other stakeholders. }\end{array}$ \\
\hline $\begin{array}{l}\text { National and } \\
\text { Global }\end{array}$ & $\begin{array}{l}\text { Western foreign policies that } \\
\text { Trovoke Mid-Eastern terrorism; } \\
\text { terrorists tend to retaliate } \\
\text { superpower dominance and } \\
\text { international favoritism. }\end{array}$ & $\begin{array}{l}\text { Victims of 9/11; ongoing } \\
\text { terrorist threats, hostages and } \\
\text { victims of anti-terrorist wars; } \\
\text { collateral damages; war- } \\
\text { devastated cities. }\end{array}$ & $\begin{array}{l}\text { Excessive national security that } \\
\text { weakens the bill of rights. Long } \\
\text { delays in airports and customs- } \\
\text { borders due to excessive checking. } \\
\text { Inconvenience of alerts. }\end{array}$ \\
\hline $\begin{array}{l}\text { Global } \\
\text { Epidemics }\end{array}$ & $\begin{array}{l}\text { Possibly poverty, malnutrition } \\
\text { and promiscuity that cause } \\
\text { HIV/AIDS and other global } \\
\text { epidemics. }\end{array}$ & $\begin{array}{l}\text { Victims of HIV/AIDS and other } \\
\text { global epidemics such as } \\
\text { SAARS and the mad cow } \\
\text { disease. }\end{array}$ & $\begin{array}{l}\text { Over 20 million deaths from HIV } \\
\text { since 1981. Ban on beef imports } \\
\text { brought about by mad cow scare } \\
\text { with resultant increases in beef } \\
\text { prices around the world. }\end{array}$ \\
\hline $\begin{array}{l}\text { National } \\
\text { Sociomoral } \\
\text { Unrest }\end{array}$ & $\begin{array}{l}\text { Various advocacy groups of } \\
\text { God-free classrooms, no-fault } \\
\text { divorce, pro-life, pro-choice, gay } \\
\text { and lesbian rights, and stem cell } \\
\text { research. }\end{array}$ & $\begin{array}{l}\text { Victims of such advocacy } \\
\text { groups: families, communities } \\
\text { negatively affected by such } \\
\text { advocacies. }\end{array}$ & $\begin{array}{l}\text { Disruption of traditional mores and } \\
\text { morality of sex, marriage and family. } \\
\text { Confusion, discomfiture and } \\
\text { demoralization of parents when } \\
\text { family members assert gay rights. }\end{array}$ \\
\hline
\end{tabular}

\subsubsection{Industrial Waste}

Another major macro product imposing serious limitations on towns, villages and communities is industrial waste (Landrigan, et al., 2018). Land and landscapes, lakes and rivers degraded by industrial deforestation, industrial effluents, abandoned railroad lines, switching yards and railroad stations are all examples. Included also are abandoned gas stations, sites and towns abandoned by industrial plant closings and impoverished neighborhoods, non-biodegradable landfills and car cemeteries. They are illustrative of macro market imperfections. We are a single-use, throwaway society. We build cars not engineered to last. Children's numerous plastic toys become a trail of industrial waste. Significant non-recyclable products such as office equipment, home products, food cans and packaging materials become industrial waste. The greater the waste, the greater is the vulnerability and disadvantage.

\subsubsection{Industrial Plant Closings}

Plant closings have existed since the birth of wage-labor. Eli Whitney's cotton gin displaced 1,000s of cotton plantation workers as robotics displace autoworkers today. There are many plant closings and layoffs throughout the U.S. economy, especially in the auto industry (Singleton, 1992). Shutdowns are not limited by industry, size or any other factor. Plant closings are natural and necessary during industrialization (Bluestone 1983). They're market imperfections causing social harm (Leahy, 1992; Leana \& Feldman, 1992). They deprive workers of their only rightful source of income (Schlack, 1991). When a firm closes a plant (retrenching many workers), the impact is felt in other community businesses which includes its customers, suppliers, distributors and competitors (Zack, 1988). Detailed reports on socio-economic disadvantages and detriments brought by industrial downsizing are available (Addison et al., 2004; Brand et al., 2008; Currie et al., 2015).

\subsubsection{Offshore Outsourcing}

One of the hottest topics in business today (Baker \& Kripalani, 2004; Irwin, 2004; Strassmann, 2004; Bruccoleri, 2018) is offshore outsourcing. The U.S. has lost over 3.3 million jobs in business services by 2004. Outsourcing today includes call-center employees to software engineers, medical specialists, lawyers and 
financial analysts. Offshore outsourcing is becoming mainstream in retail, banking, financial services, insurance, and telecom industries (Copacino, 2003). Firms are more inclined to move work offshore. An offshore vendor could take care of an entire block of internal jobs from telemarketing, call-center operators, software-code writing, desktop publishing, cost-accounting, financial analysis, transcriptions of medical and legal dictations. These jobs also include analysis of radiology output and other paralegal services, and the doing of these activities more efficiently, faster, and at far lower prices than in the U.S. These are market imperfections that generate domestic worker disadvantage (Ante, 2004; Crocket \& Ante, 2004).

\section{Solutions for Protecting the "New" Vulnerable}

Thus far we have indicated that the forced "secondary" consumption of "micro" harmful products and the forced primary consumption of "macro" harmful products are "market imperfections". These "unfavorable circumstances" generate consumer vulnerability, disadvantage and detriment, in terms of doing and becoming. Most of the market imperfections apply to "micro" and "macro" products. These market imperfections are structured, subtle, and layered within each other. They often are strongly gutted by heavy business lobbies and government bureaucracies. Micro and macro market imperfections generate consumer vulnerability (both doing and becoming). The layers of consumer detriment/harm previously listed apply to "micro" and "macro" products. The more consumers are unduly exposed or threatened by such products, the higher is their vulnerability (Karmani et al., 2016; Eagle et al., 2015). All stakeholders: manufacturers, marketers, governments, advocacy groups and the consumer communities must help.

\subsection{Protecting the "New" Vulnerable Consumers}

Here, we invoke Rogers' protective motivation theory (Prentice-Dunn \& Rogers, 1986). Accordingly, the consumer's intention to protect oneself from harmful products is enhanced by 4 critical areas of perception: 1) the severity of the risk of harmful products, 2) one's vulnerability to these risks, 3) one's ability to perform the advocated risk-reducing behavior, and 4) the desired response of achieving the desired behavior. According to Rogers' theory, the perceived costs (of the advocated risk-reducing behavior) and the perceived benefits (of the opposing risk-enhancing behavior) weaken their intentions to protect themselves from harm. When people protect themselves from harm, they consider 2 factors: (1) threat appraisal as a function of severity, vulnerability, and benefits, and (2) coping appraisal as a function of self-efficacy, response-efficacy and costs. Mostly "protection motivation" posits that consumer cognitions/perceptions of vulnerability will impact intentions directly, additively, interactively and synergistically. Thus, various stakeholders in protecting their "new" vulnerability should enhance cognitions of risk-severity and selfvulnerability of micro and macro harmful products. On the other hand, they should strengthen the selfefficacy and response-efficacy of the vulnerable with the disadvantage and detriment from these products. Media coverage on the ill effects of second hand smoking has positively deterred smokers from smoking (Slywotzky \& Morrison, 2001).

Protecting the "new" vulnerables from both "micro" and "macro" harmful products is a daunting task because there is no law nor any advocacy groups protecting these vulnerables. Yet, the harm arising from these products cannot be denied. Although the reality of the "new" vulnerables is stark, our focus is not blaming any specific groups (such as the governments, industries, corporations, shareholders, suppliers, distribution channels nor the consumers). Rather, what each stakeholder group can singly or jointly do to mitigate the social consequences of harmful micro and macro products. We advocate co-responsibility to help resolve this problem. Firms such as Kellogg's, Nestle, Merck, Johnson and Johnson, etc. have longdeclared intentions to promote healthy, nutritious, safe and/or socially valuable products.

\subsection{Social Marketing to Protect the New Vulnerable}

Societal marketing promises a fundamental reconstruction of marketing suggests greater ethical marketing that embraces social and public concerns (Andreasen, 1997). We need to look for zones where public affairs (e.g., public opinion, electoral policies, non-governmental organizations and other advocacy groups) cooperates with public policy (e.g., law, regulatory rulings and court decisions), corporate strategies 
(e.g., pricing, distribution, innovation) and consumers and local communities (see Kennedy et al., 2004). We now outline some suggestions regarding these 4 constituencies.

\subsection{What Manufacturers and Marketers can do?}

Demarketing is helpful in coping with flawed/harmful products. Kotler and Levy (1971) and Kotler (1973) discuss the appropriateness of various marketing tasks related to negative demand, overfull demand, and unwholesome demand. Addictive harmful products (see Table 1) are a case of unwholesome demand. This demand is unhealthy. The appropriate marketing task for these products is a direct no-nonsense countermarketing. This, in turn, involves the use of "warning label" ad messages, price hikes, and/or reduced product promotion and availability. This is demarketing. Lavidge (1970) encouraged marketers to stop evaluating new products based on whether they could be sold. Instead, he suggested that they evaluate them from a societal perspective of whether they should be sold. Products listed in Table 1 are of questionable social desirability. When "primary" consumption of "micro" products in Table 1 is controlled, we assume the "secondary" harmful consumption from the overindulgence is minimal. This zone of joint responsibility is between active marketers and primary consumers for these products.

\subsection{What Governments can do?}

Governments have done much in relation to both micro and macro harmful products by implementing tougher EPA standards, increasing taxes on vice products (i.e., cigarettes, alcohol and gambling). Currently, they also have higher SEC and FBI vigilance on corporate annual reports, fraudulent behaviors and bankruptcies. Similarly, the Worker Adjustment and Retraining Notification (WARN) Act of the Congress in 1988, mandates at least 6 months pre-notification of plant closings and severance benefits for laid-off employees. These measures have mitigated against the drastic impacts of ruthless plant closings and massive layoffs. Different states, moreover, are controlling the drain of jobs via offshore outsourcing. In a free capitalist marketplace, one does not advocate too many government interventions or legal changes. Ideally, we want the market forces to bring about the required equilibrium.

Instead, governments could sponsor serious empirical research on the negative effects of micro and macro products. For instance, a Report from the Surgeon General (US Department of Commerce, 1989) alleged that tobacco smoke contains over 4000 chemicals, some have marked irritant properties, and 60 of them are known or suspected to be carcinogenic. Similarly, a Report from EPA, California State (Report of the California Environmental Protection Agency: 1999), concluded that the induction and/or exacerbation of pulmonary diseases like asthma, bronchitis and pneumonia are risk factors associated with environmental tobacco smoke (ETS). After reviewing several international studies and conducting its own, the U.S. Environmental Protection Agency (EPA 1992) classified ETS as a class A carcinogen. Evidence links passive smoking to heart disease, lung, nasal, and cervical cancer. The "secondary" consumptions impact children, causing impaired learning, meningococcal infection and leukemia (Glantz \& Parmley, 1995; He et al., 1999; Report of the California EPA: 1999).

\subsection{What Consumers can do?}

Primary and secondary consumers of harmful micro products must develop mutually helping behaviors, accepting joint responsibility within homes and among peer groups (Price et al., 1995). Adolescents' tobacco disuse and their willingness to intervene to stop friends from smoking were related in consistent ways with their concepts of rights and responsibilities and to their general recognition of tobacco as a problem (Chyczewski, 2000). Responsibility should start at home. The majority of smokers are committed to protect their children from secondhand smoking (Clawson et al., 2017). Home smoking restrictions are a concrete expression of social pressure. Smokers were nearly 6 times more likely to report smoke-free homes if they lived with a nonsmoking adult and child in the household. They are more than 5 times more likely to report a smoke-free home if they believed in the harmfulness of secondhand smoking (Gilpin et al., 1999). Secondary consumers must demand their rights. Nonsmokers perceived more risk from secondhand smoke 
than smokers and are becoming more demanding of smoke-free lived home and commercial spaces. What is said of smoking applies to all micro and macro products.

\section{Concluding Remarks}

Balancing the need to respect "consumers right to choose" while ensuring that the most vulnerable ones are "protected" will continue to challenge decision makers. Combating the negative impacts of primary and secondary consumption of harmful micro and macro products is a joint responsibility and duty of all consumers, producers, marketers, governments and advocacy communities. The system provides ample opportunities for any stakeholder to appropriately respond to consumer vulnerabilities.

But complete elimination of all harm of micro and macro products is unfeasible and unrealistic. Vulnerability is a systemic part of the human condition. It makes us human. Some social externalities of both micro and macro products, as those listed in Tables 1 and 2, cannot be avoided. Their negative impacts however, must be diminished, monitored and controlled. We must reduce the harmful impacts of both harmful micro and macro products. We do this by building long-term relationships and managing social consensus among all impacted stakeholders (Deighton \& Grayson, 1995). We must be better stewards of our own resources, markets and civilization (Davis et al., 1997). Long-term human relationships and genuine stewardship of this earth and our lives will reduce our consumer vulnerabilities, especially those that relate to doing and becoming. When these vulnerabilities are controlled and minimized, consumer vulnerability of being will diminish.

Dealing with consumer vulnerabilities poses special challenges in various services sectors such as healthcare, education, entertainment or governments (Dietrich et al., 2017). Future research should focus on the developing unique approaches that service providers can adopt globally.

\section{References}

Abbott, D. A., \& Cramer, S. L. (1993). Gambling attitudes and participation: A Midwestern Survey. Journal of Gambling Studies, 9(4), 247-63.

Addison, J. T., Bellmann, L., \& Kölling, A. (2004). Works councils and plant closings in Germany. British Journal of Industrial Relations, 42(1), 125-148.

Arguder, E. (2017). Passive smoking. Güncel Göğüs Hastalıkları Serisi, 4(1), 56-68.

Andreasen, A. R. (1975). The disadvantaged consumer. New York, NY: The Free Press.

Andreasen, A. R. (1982). Disadvantaged hispanic consumers: Research perspectives and agenda. Journal of Consumer Affairs, 16(3), 46-61.

Andreasen, A. R. (1993). Revisiting the disadvantaged: Old lessons and new problems. Journal of Public Policy \& Marketing, 12(4), 270-75.

Andreasen, A. R. (1997). From ghetto marketing to social marketing: Bringing social relevance to mainstream marketing. Journal of Public Policy \& Marketing, 16(2), 129-31.

Andreasen, A. R., \& Manning, J. (1990). The satisfaction/dissatisfaction and complaining of vulnerable consumers. Journal of Consumer Satisfaction/Dissatisfaction and Complaining Behavior, 3, 12-20.

Ante, E. S. (2004). Shifting work offshore? Outsourcer beware: Quality and security woes can eat expected savings. Business Week, January 12, 36-7.

Baker, S., \& Kripalani, M. (2004). Software: Will outsourcing hurt America's supremacy? Business Week, March 1, 84-95.

Balázs, K., Bene, A., \& Hidegkuti, I. (2017). Vulnerable older consumers: New persuasion knowledge achievement measure. International Journal of Consumer Studies, 41(6), 706-713.

Bartl, M. (2010). The affordability of energy: How much protection for the vulnerable consumers. Journal of Consumer Policy, 33(3), 225-245.

Berg, L. (2015). Consumer vulnerability: Are older people more vulnerable as consumers than others? International Journal of Consumer Studies, 39(4), 284-293. 
Benton County Health Department Report. (1999). Poisoning our children: The dangers of second-hand smoke. Community Health, http://www.co.benton.or.us/health/hdp/2ndhand.htm

Bluestone, B. (1983). Deindustrialization and unemployment in America. The Review of Black Political Economy, 12(3), 29-44.

Borgmann, A. (2000). The moral complexion of consumption. Journal of Consumer Research, 26(4), 418-422.

Brand, J. E., Levy, B. R., \& Gallo, W. T. (2008). Effects of layoffs and plant closings on subsequent depression among older workers. Research on Aging, 30(6), 701-721.

Bruccoleri, M. (2018). The magnitude of a product recall: Offshore outsourcing vs. captive offshoring effects. International Journal of Production Research, 1-17.

Calfee, J. E., \& Bate, R. (2004) Pharmaceutical and the worldwide HIV epidemic: Can a stakeholder model work? Journal of Public Policy \& Marketing, 23(2), 140-52.

Chan, S. H., \& Ghani, M.A. (2011). The impact of microloans in vulnerable remote areas: Evidence from Malaysia. Asia Pacific Business Review, 17(1), 45.

Caplovitz, D. (1963). The poor pay more: Consumer practices of low-income families. New York, NY: The Free Press.

Carey, J., \& Gross, N. (2004). Second-hand smoke: A quick study. Business Week, April 19, 83.

Chyczewski, S. M. (2000). Adolescent perceptions of rights and responsibilities related to tobacco use and secondhand smoke. Dissertation Abstracts International: Section B: The Sciences \& Engineering, August.

Clawson, A.H., McQuaid, E. L., \& Borrelli, B. (2017). Smokers who have children with asthma: perceptions about child secondhand smoke exposure and tobacco use initiation and parental willingness to participate in child-focused tobacco interventions. Journal of Asthma, 55(4), 373-384.

Copacino, W. C. (2003). Take a look at business process outsourcing. Logistics Management, 42(7), 70-71.

Cowan, R. S. (1979). From Virginia dare to Virginia slims: Women and technology in American life. Technology and Culture, 20(1), 51-63.

Crisp, R. (1987). Persuasive advertising, autonomy, and the creation of desire. Journal of Business Ethics, 6(June), 413418.

Crocket, R. O., \& Ante, S. E. (2004). Services: Farming it out at a faster pace. Business Week, January 12, 98.

Currie, J., Davis, L., Greenstone, M., \& Walker, R. (2015). Environmental health risks and housing values: Evidence from 1,600 toxic plant openings and closings. American Economic Review, 105(2), 678-709.

Davidson, D. K. (2003). Selling sin: The marketing of socially unacceptable products. Westport, CT: Praeger Publishers.

Davis, J. H., Schoorman, D. F., \& Donaldson, L. (1997). Toward a stewardship theory of management. The Academy of Management Review, 22(January), 20-48.

Dey, B. (2017). A review article on passive smoking. Indian Research Journal of Pharmacy and Science, 4(3), $1164-1169$.

Deighton, J., \& Grayson, K. (1995). Marketing and seduction: Building exchange relationships by managing social consensus. Journal of Consumer Research, 21(4), 660-76.

Diener, B. J. (1993). The frequency and context of alcohol and tobacco cues in daytime soap opera programs: Fall 1986 and Fall 1991. Journal of Public Policy \& Marketing, 12(Fall), 252-57.

Dietrich, T., Trischler, J., Schuster, L., \& Rundle-Thiele, S. (2017). Co-designing services with vulnerable consumers. Journal of Service Theory and Practice, 27(3), 663-688.

Dietz, W. (1991). Factors associated with childhood obesity. Nutrition, 7(4), 290-91.

Eagle, L., Desrochers, D., Dahl, S., Mahony, T., \& Low, D. R. (2015). Promotion of harmful products. Marketing Ethics \& Society. London: Sage, 159-188.

Flegal, K. M., Carroll, M. D., Ogden, C. L., \& Johnson, C. L. (2002). Prevalence and trends in obesity among US adults, 1999-2000. Journal of the American Medical Association, 288(14), 1723-25.

Garrett, D. E., \& Toumanoff, P. G. (2010). Are consumers disadvantaged or vulnerable? An examination of consumer complaints to the Better Business Bureau. The Journal of Consumer Affairs, 44(1), 3-23.

Gellad, W. F., Huskamp, H. A., Phillips, K. A., \& Haas, J. S. (2006). How the new Medicare drug benefit could affect vulnerable populations. Health Affairs, 25(1), 248-55.

Gilpin, E.A., White, M. M., Farkas, A. J. \& Pierce, J. P. (1999). Home smoking restrictions: Which smokers have them and how they are associated with smoking behavior. Nicotine \& Tobacco Research, 1(June), 153-162. 
Glantz, S. A. \& Parmley, W. W. (1995). Passive smoking and heart disease. Journal of American Medical Association, 275(13), 1047-1053.

Goodman, C. (1968). Do the poor pay more? Journal of Marketing, 32, 18-24.

Graham, C. (2018). Tackling consumer vulnerability in energy and banking: Towards a new approach. Journal of Social Welfare and Family Law, 40(2), 241-261.

Haviland, A. M., Sood, N., McDevitt, R., \& Marquis, M. (2011). How do consumer-directed health plans affect vulnerable populations? Forum for Health Economics \& Policy, 14(2), 1-23.

He, J., Vupputuri, S., Allen, K., Prerost, M. R., Hughes, J., \& Whelton, P. K. (1999). Passive smoking and the risk of coronary heart disease: A meta-analysis of epidemiologic studies. New England Journal of Medicine, 340, 920-6.

Harrison, P., \& Gray, C. (2010). The ethical and policy implications of profiling 'vulnerable' customers. International Journal of Consumer Studies, 34(4), 437-442.

Hudson, M. (1993). How the poor pay more: Big premiums on big ticket items. Business and Society Review, 85, 43-6.

Irwin, D. (2004). Outsourcing is good for America. Wall Street Journal, January 28, editorial page.

Janssen, H. G., Davies, I. G., Richardson, L.D., \& Stevenson, L. (2018). Determinants of takeaway and fast food consumption: A narrative review. Nutrition Research Reviews, 31(1), 16-34.

Karnani, A., McFerran, B., \& Mukhopadhyay, A. (2016). The obesity crisis as market failure: An analysis of systemic causes and corrective mechanisms. Journal of the Association for Consumer Research, 1(3), 445-470.

Karpatkin, R. H. (1999). Toward a fair and just marketplace for all consumers: The responsibilities of marketing professionals. Journal of Public Policy \& Marketing, 18(1), 118-122.

Kennedy, C. R., Harris, F., \& Lord, M. (2004). Integrating public policy and public affairs in a pharmaceutical marketing program: The AIDS pandemic. Journal of Public Policy \& Marketing, 23(2), 128-139.

Knobel, B. (2018). America's most vulnerable, the watchdog still barks. Fordham University Press.

Kotler, P. (1973). The major tasks of marketing management. Journal of Marketing, 37(Oct), 42-49.

Kotler, P., \& Levy, S. J. (1971). Protective marketing, yes, protective marketing. Harvard-Business Review, 49(Nov-Dec), 74-80.

Landrigan, P. J., Fuller, R., Hu, H., Caravanos, J., Cropper, M. L., Hanrahan, D., \& Suk, W. A. (2018). Pollution and global health: An agenda for prevention. Environmental Health Perspectives, 126(8).

Lavidge, R. J. (1970). The growing responsibilities of marketing. Journal of Marketing, 34(Jan), 25-28.

Leahy, P. J. (1992). Plant closings: A Comparison to natural disasters. American Journal of Economics and Sociology, 3 , 338- 348.

Leana, C. R. \& Feldman, D. C. (1992). How individuals, organizations, and communities respond to layoffs. Lexington Books.

Loewy, E. H. (1993). First or second class? Is building health care systems like running an airline? Business and Professional Ethics Journal, 12(3), 69-82.

Manson, J. E., \& Bassuk, S. S. (2003). Obesity in the United States: A fresh look at its high toll. Journal of the American Medical Association, 289(2), 229-30.

Mclntyre, P. (2004). A high price to pay; Workers lives lost to secondhand smoke. Nation's Restaurant News, Opinion Section, August 16.

Monteiro, C. A., Moubarac, J. C., Levy, R. B., Canella, D. S., da Costa Louzada, M. L., \& Cannon, G. (2018). Household availability of ultra-processed foods and obesity in nineteen European countries. Public Health Nutrition, 21(1), 18-26.

Morris, L. A., Tabak, E. R. \& Olins, N. J. (1992). A segmentation analysis of prescription drug information-seeking motives among the elderly. Journal of Public Policy \& Marketing, 11(Fall), 115-25.

Nason, R. W. (1989). The social consequences of marketing: Macromarketing and public policy. Journal of Public Policy \& Marketing, 8, 242-51.

Nichols, M. W., Stitt B. G., \& Giacopassi, D. (2000). Casino gambling and bankruptcy in new United States Casino Jurisdictions. The Journal of Socio-Economics, 29(May), 247-50.

Outka, G. (1987). Social justice and equal access to health care in bioethics (3rd edition). Ed. Thomas A Shannon, Mahwah, NJ: Paulist Press, 503-526.

Pasternak, A. V. (1997). Pathological gambling: America's Newest Addiction? American Family Physician, 56, 1293-1298. 
Prentice-Dunn, S., \& Rogers, R. W. (1986). Protection motivation theory and preventive health: Beyond the Health Belief Model. Health Education Research, 1(3), 153-161.

Patterson, L. T., Hunnicutt, G. G., \& Stutts, M. A. (1992). Young adults' perceptions of warnings and risks associated with alcohol consumption. Journal of Public Policy \& Marketing, 11(Spring), 96-103.

Price, L. L., Feick, L. F., \& Guskey, A. (1995). Everyday market helping behavior. Journal of Public Policy \& Marketing, 14(Fall), 255-66.

Purviance, S. M. (1993). Kidney transplantation policy and distributive justice. Business and Professional Ethics Journal, 12(2), 19-37.

Rawls, J. (1971). A theory of justice. Cambridge, MA: Harvard University Press.

Reno, R. A. (1996). The iceman cometh: Will gambling be a bad bet for your town? The Journal of American Citizenship, 76(Mar/Apr), 1-6.

Schlack, R. F. (1991). Plant closings: A community's bill of rights. Journal of Economic Issues, 25(2), 511-518.

Seiders, K., \& Petty, R. D. (2004). Obesity and the role of food marketing: A policy analysis of issues and remedies. Journal of Public Policy \& Marketing, 23(2), 153-169.

Shaffer, H. J., \& Hall, M. N. (1996). Estimating the prevalence of pathological gambling disorders. Journal of Gambling Studies, 12, 193-214.

Sheth, J. N., \& Mittal, B. (2003). Customer behavior: A managerial perspective (2nd Edition). Thomson Learning.

Singleton, C. J. (1992). Auto industry jobs in the 1980s: A decade of transition. Monthly Labor Review, February, 18-27.

Slywotzky, A., \& Morrison, D. (2001). The rise of the active consumer. Marketing Management, 10(2), 22-26.

Smith, C. N., \& Cooper-Martin, E. (1997). Ethics and target marketing: The role of product harm and consumer vulnerability. Journal of Marketing, 61(July), 1-20.

Spratlen, T. H. (1992). Targeting blacks in cigarette advertising: Knowledge of externalities using secondary research. AMA Winter Educators' Proceedings, 3, 517-24.

Springhart, H., \& Thomas, G. (2017). Exploring vulnerability. Göttingen: Vandenhoeck \& Ruprecht.

Stern, L. W., \& Eovaldi, T. L. (1984). Legal aspects of marketing strategy: Antitrust and consumer protection issues. Englewood Cliffs, NJ: Prentice-Hall.

Strassmann, P. A. (2004). Most outsourcing is still for losers. Computerworld, 38(5), 25.

Sturdivant, F. D. (1969). The ghetto marketplace. New York: The Free Press.

Timmermann, S. (2009). Protecting the most vulnerable from financial abuse: What should we know? Journal of Financial Service Professionals, 63(3), 23.

Volberg, R. A. (1995). The Prevalence and demographics of pathological gamblers: Implications for public health. American Journal of Public Health, 84, February.

Wansink, B. (2016). Slim by design: Mindless eating solutions for everyday life. Hay House, Inc.

Watson, S., Liddell, P., Moore, R. S., \& Eshee, W. D. (2004). The legalization of internet gambling: A consumer protection perspective. Journal of Public Policy \& Marketing, 23(2), 209-13.

Williams, J. D. (1991). Reflections of a Black middle-class consumer: Caught between two worlds or getting the best of both? Advances in Consumer Research, 19, 850-56.

Williams, J. D. (1995). Racially exclusive real estate advertising: Public policy implications for fair housing practices. Journal of Public Policy \& Marketing, 14(2), 225-244.

Wilson, T. (2012). Supporting social enterprises to support vulnerable consumers: The example of community development finance institutions and financial exclusion. Journal of Consumer Policy, 35(2), 197-213.

Wilson, T., Howell, N., \& Sheehan, G. (2009). Protecting the most vulnerable in consumer credit transactions. Journal of Consumer Policy, 32(2), 117-140. 